\title{
Sundhed - En ny semi-religiøs vækkelse i moderne samfund?
}

Tidsskrift for Forskning i Sygdom og Samfund

Nr. 17, 2012 


\section{Tidsskrift for Forskning i Sygdom og Samfund}

\section{Nr. 17: Sundhed - En ny semi-religiøs vækkelse i moderne samfund?}

\section{(c) 2012 forfatterne og udgiverne.}

Redaktion:

Mette Bech Risør (ansv.), Forskningsenheden for Almen Praksis, Universitetet i Tromsø

Torsten Risør, Allmennmedisin, Institutt for Samfunnsmedisin, Universitetet i Tromsø Gitte Wind, Afdeling for Antropologi og Etnografi, Aarhus Universitet

Ann Dorrit Guassora, Forskningsenheden for Almen Praksis, Københavns Universitet Susanne Rewentlow, Forskningsenheden for Almen Praksis, Københavns Universitet Rikke Sand Andersen, Forskningsenheden for Almen Praksis, Aarhus Universitet Claus Bossen, Institut for Medie- og Informationsvidenskab, Aarhus Universitet

Gxsteredaktør:

Nanna Mik-Meyer, CBS, Københavns Universitet

Anne Roelsgaard Obling, CBS, Københavns Universitet

Peer review: Foretages af et tværvidenskabeligt panel bestående af bl.a. læger, antropologer, filosoffer, historikere, psykologer, politologer og sociologer.

Proof: Thomas Christian Mikkelsen

Layout og prepress: Thomas Christian Mikkelsen \& Ea Rasmussen

Tryk: Werk Offset, Højbjerg.

Udgiver:

Foreningen Medicinsk Antropologisk Forum,

Afd. for Antropologi og Etnografi, Aarhus Universitet, Moesgård, 8270 Højbjerg.

Bestilling, abonnement, henvendelser og hjemmeside:

Tidsskrift for Forskning i Sygdom og Samfund.

Afd. for Antropologi og Etnografi, Aarhus Universitet, Moesgård, 8270 Højbjerg

Torsdag kl. 12-15, tlf. 87162063,

Email: sygdomogsamfund@hum.au.dk

Hjemmeside og artikler online:

ojs.statsbiblioteket.dk/index.php/sygdomogsamfund/index

ISSN (tryk): 1604-3405

ISSN (online): 1904-7975

Tidsskriftet er udgivet med støtte fra Forskningsrådet for Kultur og Kommunikation.

Formål:

Tidsskrift for Forskning i Sygdom og Samfund er et tværfagligt tidsskrift, der tager udgangspunkt i medicinsk antropologi. Tidsskriftet har til formål at fremme og udvikle den forskning, der ligger i grænsefeltet mellem sundhedsvidenskab og humaniora/samfundsvidenskab. Tidsskriftets målsætning er at fungere som et forum, hvor disse fag kan mødes og inspirere hinanden - epistemologisk, metodisk og teoretisk - i forskellige forskningssammenhænge. Tidsskriftet formidler den debat og teoretiske udvikling, der foregår i de voksende faglige samarbejds- og forskningsinitiativer, der udspringer af dette grænsefelt. Tidsskriftet henvender sig til alle med interesse for forskning i sygdom og samfund og i særlig grad til sundhedsmedarbejdere i forsknings- og undervisningssammenhæng med forbindelse til tværfaglige miljøer.

Aims and scopes

The Journal for Research in Sickness and Society is an interdisciplinary journal which has a theoretical background in medical anthropology. The aim and purpose of the journal is to promote and develop research in the borderland between the health sciences and the humanities/the social sciences. The goal of the journal is to function as a forum in which these disciplines may meet and inspire each other epistemologically, methodologically and theoretically. The journal conveys the debate and theoretical development which takes place in the growing collaboration and research initiatives emerging from this borderland. The journal addresses all with an interest in research in sickness and society and especially health professionals working with education and/or research in interdisciplinary institutions. 


\section{Indhold}

Nanna Mik-Meyer \& Anne Roelsgaard Obling

Introduktion 5-12

Monica Greco

Om livets kunst: en vitalistisk læsning af medicinsk humanisme 13-38

Nanna Mik-Meyer

Legitimt syg: klasse og køn i sygdomsfortællinger 39-58

Anne Roelsgaard Obling

Træning af kontrolleret empati i accelererede kræftbehandlingsforløb 59-78

Anette Lykke Hindhede

Normer, normalisering og det hørehæmmede subjekt 79-100

Bjarke Oxlund

At leve gennem tal: Brugen af måleapparater i håndteringen af livsstilssygdomme i Danmark 101-118

Kaspar Villadsen \& Kathrine Hoffman Pii

Forebyggelse på tværs af det offentlige og private: Når patienter trodser myndiggørelse og efterspørger mere professionel involvering 119-142

Morten Hulvej Rod \& Tine Curtis

At udskyde det uundgåelige: Om brugen af kausal viden i forebyggende tiltag $143-162$

Abstracts in English 163

Forfatterliste 169

Skrivevejledning 171

Beskrivelse af nr. 18174 


\section{Træning af kontrolleret empati i accelererede kræftbehandlingsforløb}

\section{Anne Roelsgaard Obling}

CBS, Københavns Universitet ar.ioa@cbs.dk

Obling, A.R. (2012). Træning af kontrolleret empati i accelererede kræftbehandlingsforløb. Tidsskrift for forskning i Sygdom og samfund, nr. 17, 59-78.

Denne artikel gør brug af et følelsessociologisk perspektiv til at undersøge træning af empati og empatisk respons $i$ accelererede kræftbehandlingsforløb. Artiklen tager udgangspunkt $i$ en træningsworkshop i empatisk kommunikation, hvor hospitalslæger fra en kræftafdeling lærer at genkende og kontrollere patienters følelser i lege-patient interaktioner. Gennem en deskriptiv analyse af workshoppen undersøges hoordan specifikke følelsesstyringsteknikker trænes samt hoilken effekt denne træning har. Analysen adresserer hoordan mantraet om "mere empati" $i$ klinisk praksis virker som et indirekte middel til at kultivere lægers adfærd. Artiklen diskuterer afslutningsvist hvordan aktuelle reformer $i$ det danske sundhedsvæsen - i form af implementering af accelererede behandlingsregimer - genaktiverer et fokus på humanistiske værdier $i$ medicinske møder. Pointen er at disse værdier i stigende omfang bliver gjort til genstand for kvalitetsforbedringstiltag og dokumentationspraksis. Med andre ord indebærer forsøg på at forbedre de såkaldte bløde dimensioner, at disse dimensioner samtidig standardiseres - herunder udførelsen af empatisk engagement. I denne artikel undersøges træning af empati og empatisk respons i medicinsk arbejde. Mere specifikt fokuserer den på, hvordan styring af følelser (patienters såvel som lægers følelser) kan trænes som led i et forsøg på at rationalisere og standardisere sundhedsprofessionelles ekspertise og adfærd. Samtidig undersøges, hoordan denne træning er et udtryk for en tendens $i$ samtiden, nemlig bestræbelsen på at gøre medicinske ydelser - herunder mødet mellem lager og patienter - mere humane. 
Introduktionen af kræftpakkerne i 2008 har ført til en reorganisering af kræftsygdomme og deres behandling. Kræftpakker eller accelererede kræftbehandlingsforløb er blevet udviklet som et forsøg på at begrænse omkostninger i en tid med stigende udgifter til sundhedsvæsnet, begrænsede offentlige ressourcer og en politisk opmærksomhed rettet mod styrkelse af patientens valg (patienten i centrum retorik). Behandlingskonceptet tager afsæt i kliniske interesser i det kræftpatienters overlevelsesmuligheder efter kræftsygdom er væsentlige lavere i Danmark end i de nordiske nabolande (Sundhedsstyrelsen, 2000). Forsøget på at effektivisere og strømline behandlingsforløb, så patienter får den rette behandling til den rette tid ved hjælp af de bedst mulige kliniske ressourcer, er dog ikke kun et dansk fænomen, men kendes eksempelvis også fra det engelske sundhedsvæsen, NHS (jf. Harrison og McDonald, 2008).

De accelererede forløb udspringer af en ambition om, at patientens vej gennem systemet - fra undersøgelser, behandling, efterbehandling, udskrivelse og kontrol følger en nøje standardiseret plan (Sundhedsstyrelsen, 2008b). Forløbene er opdelt i standardiserede medicin-, speciale- og behandlingsmoduler - fulgt af planer for samarbejde mellem sundhedsprofessionelle, afdelinger og sektorer og information til patienter og pårørende. De er desuden omfattende monitorerede, så man i de enkelte kræftpakker kan følge med i om eksempelvis behandlingsgarantien overholdes. Opkomsten af disse accelererede behandlingsregimer forandrer den måde, hvorpå det medicinske arbejde er organiseret og det forandrer den måde, hvorpå arbejdet udføres. Det betyder samtidig også, at en ny generation af lokale arbejdspraksisser indføres - herunder standardiserede følelsesprogrammer, der har konsekvenser for, hvordan sundhedsprofessionelle forventes at handle og engagere sig emotionelt i professionel-patient interaktioner.

Accelererede kræftbehandlingsforløb indgår på den ene side som et led i en klinisk strategi om, at forbedre kræftpatienters generelle sundhedsoutcome ved at tilbyde hurtigere og mere effektiv behandling. På den anden side er forløbene et symptom på New Public Management reformer og forsøg på at rationalisere professionelles arbejde i velfærdsinstitutioner (Hood, 1991; Power, 1997; Du Gay, 2000, Miller og Rose, 2008). Generelt er det hensigten at gøre disse institutioner herunder offentlige hospitaler - mere ansvarlige, kundeorienterede og effektive i deres brug af ressourcer. Denne påskyndelse til performanceforbedringer indebærer en bevægelse i retning af rationalisering af medicinsk arbejde. Som en ny form for styring omfatter denne rationaliseringstrang ikke kun de såkaldte hårde dimensioner af medicinsk arbejde (EBM, kliniske procedurer, økonomiske incitamenter, sikkerheds- og evalueringsværktøjer), men også et udtalt fokus på bløde 
dimensioner af lægefaglige ydelser. Jeg kalder disse dimensioner bløde, fordi de blandt andet omfatter de måder, hvorpå ansatte i sundhedsvæsnet i dag forventes at gøre sig emotionelt tilgængelige for patienter gennem facilitering af "partnerskabsrelationer" mellem læge og patient (Bub, 2004) og "patient-centrerede" aktiviteter (Mead og Bower, 2000).

Artiklen tager udgangspunkt i denne konfiguration af sundhedsprofessionelles arbejde og viser hvordan lægers emotionelle engagement $i$ dag er genstand for styringsforsøg, der sigter mod at strukturere og styre interaktionen mellem patienter og læger samt at kultivere lægers individuelle handlinger i disse interaktioner. I artiklen præsenteres empirisk materiale fra en træningsworkshop i empatisk kommunikation. Workshoppen blev afholdt på et større universitetshospital i Danmark og deltagerne i workshoppen var læger og sygeplejersker fra en kirurgisk kræftafdeling. Det kliniske problemfelt som workshoppen adresserede, var den vanskelige samtalesituation, hvor informationer om diagnose, behandlingsplan og eventuelt sygdomsprognose leveres til patienter i ambulatoriet. Træningen involverede blandt andet at læger deltog i rollespil på en scene for at træne samtalesituationen. Formålet med workshoppen var at gøre denne situation mere effektiv, spare tid og forbedre kvaliteten af både den patient- og lægeoplevede kvalitet via facilitering af empati.

Artiklen er struktureret som følgende. Først undersøges hvordan teknikker for empatisk kommunikation kan trænes som følelsesstyringsteknikker til, at læger kan blive i stand til at genkende og kontrollere den følelsesmæssige ramme for læge-patient interaktioner. Dernæst diskuteres hvorvidt træning af lægers følelsesarbejde er påvirket af politisk moderniseringstænkning, der med afsæt i New Public Management reformer vægter effektivisering, målbarhed og kvalitetsudvikling samtidig med, at tilsyneladende mere humane interaktionsformer efterstræbes i denne reformbevægelse.

\section{Følelser og følelsesstyring i organisationer}

Empati eller empatisk respons bruges ofte i den medicinske praktikerlitteratur til at beskrive og indramme det emotionelle forhold mellem læger og patienter (jf. Halpern, 2001; Mark, 2005). Larson og Yao (2005) definerer empati som en magtfuld færdighed (2005: 1100) og foreslår, at empatisk respons kan læres gennem intensiv kommunikationstræning. Forfatterne hævder at læger er mere effektive og nyder mere arbejdsglæde, hvis de erkender, at deres arbejde omfatter håndtering af følelser, og hvis de refleksivt engagerer sig i arbejdet med at koordinere og sty- 
re følelser i læge-patientinteraktioner - her tænkes både på koordination af egne samt patienters følelser. Træning $\mathrm{i}$ at styre følelser omfatter både styring af de følelser, som indgår i den konkrete samtalesituation i klinikken samt håndtering af eftervirkninger af et ofte stressende job. Larson og Yao identificerer et behov for at man i løbet af den medicinske uddannelse - samt i det efterfølgende arbejdsliv - tilbyder læger undervisning i emotionelle færdigheder. Dette argument bakkes op i tilsvarende litteratur, der beskæftiger sig med uddannelsesdimensionen af empati (jf. Teherani et al., 2008; Neumann et al., 2009). Argumentet er at hvis eksempelvis empatiske færdigheder eksplicit trænes og efterfølgende bruges aktivt i praksis, vil læger opleve mindre stress på jobbet og muligheder for udbrændthed vil blive reduceret.

Ideen om at organisationer og deres ansatte strategisk trænes i at bruge følelser til at opnå bestemte organisatoriske mål er ikke ukendt inden for følelsessociologien. Goffman (1959) bruger begrebet "the arts of impression management" til at henvise til det udvalg af teknikker og kompetencer, der kræves af medarbejdere " i arbejdet med at opføre en rolle på en vellykket måde" (1959: 203). Det indebærer at præsentere sig selv på strategiske måder for at fremme gunstige indtryk i andre. Mange performere, hvis job indebærer at samhandle socialt - eksempelvis sundhedsprofessionelle, socialrådgivere og advokater - holder ifølge Goffman forberedelse til deres offentlige optræden skjult i kulisserne bag scenen. Det gælder også træning af de indtryks- eller følelsesstyringsteknikker som guider måden, hvorpå professionelle performere må opføre følelser offentligt og hvilke følelser, der skal spilles på i udvalgte situationer.

For organisatoriske aktører kræver det træning og til tider hårdt arbejde at lære at styre andres indtryk og at blive anerkendt som "skilled emotion managers" (Bolton og Boyd, 2003). Nogle følelser kan i sociale interaktioner anvendes som "emotions of control" (Fineman and Sturdy, 1999), hvilket igen betyder, at raffineret følelsesstyring - herunder teknikker til selvkontrol - kan bruges til at regulere arbejdsprocesser og stabilisere sociale interaktioner.

Hochschild (1983) anvender begrebet "emotional labour" om arbejde, der omfatter "the management of feeling to create a publicly observable facial and bodily display" (1983: 7). Det vil sige, at ansatte - typisk servicemedarbejdere - aflønnes for at producere en positiv eller negativ emotionel tilstand i andre. Hendes kritik er at disses følelsesarbejde kommercialiseres i det offentlige rum på bekostning af deres private følelser, der nu leveres som en del af serviceydelsen og konsumeres af kunder, som en varegjort social interaktion i et kapitalistisk bytteforhold. Ifølge Hochschild kan vi betragte følelser som en skjult ressource, der kan organiseres 
og reguleres ligesom viden, penge eller fysisk arbejde, det vil sige ressourcer som organisationer behøver for at få opgaver udført og for at nå deres målsætninger. Hun undersøger eksempelvis det følelsesarbejde som udføres af stewardesser i det amerikanske flyselskab Delta Airlines. Hensigten med stewardessernes følelsesarbejde er, at fremme et godt image for selskabet, som samtidig kan overbevise kunderne om, at de får en varm, unik og personlig service, hvilket giver indtryk af, at selskabets kundeservice er af høj kvalitet.

Hvis man retter blikket mod sundhedsprofessionelle, så ser man, at følelsesarbejde der udføres af læger er mere komplekst end det arbejde, der udføres af det såkaldte "følelsesproletariat" - herunder stewardesser, frisører, fitness instruktører og serveringspersonale. Læger er højt betalte for deres kompetencer inden for følelsesstyring, og de teknikker og manuskripter, som styrer deres specifikke emotionelle engagement, er en integreret del af den lægefaglige professionalisme frem for blot at være en del af kommercielle interesser (Fineman, 1993; Bolton, 2005; Mann, 2005). Professionen gør således brug af formaliserede følelsesindtryk og repræsenterer en bestemt form for emotionel adfærd i medicinske interaktioner for at fastholde deres professionelle identitet og rolle i relationer til patienter, pårørende, kollegaer m.m. Ofte må læger balancere mellem følelsesregler, der er dikteret af deres profession og instrumentelle krav, der pålægges dem i form af f.eks. sundhedsreformtiltag og lokale ledelsesstrategier og målsætninger. Denne balancegang har indflydelse på, hvilken emotionel adfærd de forventes at udvise.

I en tid hvor effektivitet, stram økonomistyring og brugertilfredshed er på politiske og administrative dagsordener; hvor arbejdsprocedurer standardiseres og medicinske interaktioner accelereres, så professionelles engagement med patienter ofte er reduceret til "nanosekund emotionalitet" (Bone, 2002: 141), kan en af konsekvenserne vel være, at følelsesarbejde, der er forankret i professionens normer og værdier, påvirkes til fordel for udvisning af følelsesarbejde, der hovedsagligt finder sted som del af et effektiviseringsprogram. Hertil kræves at den organisatoriske forvaltning af følelser opfattes som et teknisk problem, som kan ekspliciteres, finjusteres og koordineres gennem omskoling af professionelle.

\section{Empirisk materiale}

Materialet der anvendes i denne artikel er indsamlet som en del af et feltarbejde udført i forbindelse med min ph.d. afhandling. Det foregik på et større offentligt universitetshospital og fokuserede på reorganisering af kræftsygdomme og deres behandling - herunder hospitalslægers følelsesarbejde i accelererede kræft- 
behandlingsforløb. I herværende artikel inddrager jeg deltagerobservationsmateriale, semi-strukturerede interview og dokumenter fra en træningsworkshop, hvor læger og sygeplejersker fra en kræftafdeling deltog. Jeg fik adgang til workshoppen som almindelig deltager. Workshoppen varede cirka syv timer. I alt 18 medarbejdere deltog - heraf otte læger (kvindelige og mandlige overlæger og reservelæger), otte sygeplejersker (kvindelige), to konsulenter (en kvindelig psyko$\log$ og en kvindelig uddannelseskonsulent). Nogle af lægerne havde været ansat i kræftafdelingen i mange år, mens andre var forholdsvis nytilkomne. Det samme var tilfældet med de involverede sygeplejersker. Jeg har valgt at fokusere udelukkende på lægernes performances for at undersøge træning og kultivering af lægefaglige aktiviteter gennem brug af følelsesstyringsteknikker.

Jeg havde på forhånd lovet ikke at bånde rollespillene. Derfor tog jeg i stedet noter under workshoppen, der dækker observerede aktiviteter samt uformelle samtaler, jeg havde med deltagerne undervejs. Deltagernes udtalelser er omskrevet således at de fremstår som anonyme udtalelser og ikke kan ledes tilbage til navngivne personer. Derudover er tre kvalitative interview med henholdsvis en konsulent (personen der leder workshoppen) og to klinikledere (klinikchef og oversygeplejerske) inkluderet i materialet. Det primære fokus for interviewene var at få indsigt i tilblivelsen af workshoppen samt at forstå, hvorfor informanterne anså workshoppen som nødvendig for afdelingens kvalitets - og kompetenceudvikling. De tre interviews havde hver en times varighed og blev udført på hospitalet. Interviewene er efterfølgende transskriberet $\mathrm{i}$ deres helhed.

\section{Præsentation af kontekst}

Behandlingsforløbene i afdelingen er blevet reorganiseret i takt med den landsdækkende indførelse af pakkeforløb for kræftpatienter der fandt sted i 2008 (Sundhedsstyrelsen, 2008a; 2008b). Samtidig har afdelingen lokalt indført accelererede processer i store dele af forløbene. De reorganiserede behandlingsforløb omfatter et forstærket fokus på regulerede arbejdsopgaver, ventetidsmålsætninger og dokumentationsopgaver. Ethvert møde mellem læge og patient er nu en realisering af en standardiseret skriftligt procedureplan, som skal følges, og som også inkluderer en procedure for patientsamtaler forløbet igennem. I de accelererede forløb er der indbygget et fokus på udvikling af kommunikationsfærdigheder, herunder empatiske respons-færdigheder. Antagelsen er at bedre kommunikation mellem kræftpatient og læge ikke blot forbedrer det generelle udbytte af diagnostik og behandling, men også understøtter de fremskyndede procedurer for medicinske 
indgreb undervejs i forløbet. I henhold til krav om effektiv kommunikation, som blandt andet er formuleret i Sundhedsstyrelsens pakkeforløbsbeskrivelser (ibid.), er en god læge defineret som en læge, der mestrer forskellige kommunikative kompetencer. Som en kompetence kan kommunikation udvikles og bruges af læger til at hjælpe med at koordinere handlinger og følelser, der udspilles i interaktioner med patienter. Centralt for disse ideer om kommunikativ kompetence er, hvordan kommunikation kan mobiliseres som et middel til at kultivere lægers adfærd (jf. May m.fl., 2006). Ved samtidig at hævde at problemer i interaktioner mellem patienter og læger er af teknisk art, kan uddannelse i at kommunikere empatisk identificeres i forløbsbeskrivelserne, som en mulig problemløsning på relationelle uoverensstemmelser.

Herudover skal varetagelsen af empatisk kommunikation med patienter dokumenteres i patientjournaler, og afdelingen skal som led i regionale kvalitetsplaner sikre, at patienterne føler sig trygge undervejs i deres forløb, og at de er velinformerede om diagnose og behandlingsplaner (Region Hovedstaden, 2010).

Den træningsworkshop som beskrives i denne artikel, kan ses som en foranstaltning, der har to formål. På den ene side styrker den gennem intensiv træning dele af den strukturelle reorganisering af kræftforløbene. Den fokuserer på overlevering af information og håndtering af den svære samtale. På den anden side imødekommer den konkrete behov fra de sundhedsprofessionelles side idet de har efterspurgt uddannelse i effektive kommunikationsfærdigheder. Workshoppen er således ikke blot en fiks ide fra ledelsens side, men også et ønske fra medarbejderne i klinikken og derved også et resultat af personalets krav om mere uddannelse i empati og empatisk respons. Målet med workshoppen blev i programmet beskrevet som:

"at deltagerne ud fra nogle kommunikative værktøjer bliver i stand til at styre og strukturere en svær patientsamtale med større grad af bevidsthed om, hvad den enkelte selv bidrager med både fagligt og personligt i samtalen og i forhold til samarbejdet".

Opførelsen af en respektfuld samtale mellem patienter og sundhedsprofessionelle udlægges ofte som et spørgsmål om at være i besiddelse af kommunikative færdigheder. I programmet forklares, at:

"færdigheder i at kommunikere kan læres og er ikke blot et spørgsmål om at have de rigtige personlighedstræk eller stil. Forskning har vist, at færdigheder i kommunikation giver en mere effektiv konsultation for både den sundhedsprofessionelle og patienten, større patienttilfredshed og forøger patientens velbefindende". 
Programmet understreger at det ikke er medfødt, naturlig kompetence at være en god kommunikator - selv om der i mange arbejdssammenhænge findes en commonsense overbevisning om, at nogle medarbejdere har det i sig og andre ikke. Kommunikationsteknikker beskrives her som tillærte og trænede færdigheder, der er nødvendige for at et empatisk møde mellem læge og patient kan finde sted. Samtidig er disse teknikker nødvendige for et succesfuldt - herunder accelereret - behandlingsforløb og lægerne inviteres derfor til at træne dem på workshoppen. De emotionelle komponenter, der indgår i kommunikation, kan også beskrives som følelsesarbejde (jf. Hochschild, 1983). Denne type arbejde omfatter genkendelse og håndtering af patienters følelser gennem bevidstgjorte og tillærte følelsesstyringsteknikker, som eksempelvis træning af empatiske samtalefærdigheder. I de følgende afsnit vil jeg se nærmere på, hvordan følelsesstyringsteknikker tillæres undervejs i workshoppen - samt hvordan disse udlægges og forstås af konsulenter såvel af deltagere.

\section{Træningssessionen}

På en regnfuld oktobermorgen samles halvdelen af afdelingens sygeplejersker og læger i et uddannelseslokale der tilhører det offentlige universitetshospital, som kræftafdelingen er en del af. Afdelingsledelsen har deltaget i et lignende seminar den foregående dag og er derfor ikke til stede. Deltagerne mødes af to udviklingskonsulenter som, i kraft af deres rolle som værter for workshoppen, byder dem velkommen. Workshoppen består af tre forskellige dele: en mundtlig præsentation af hvordan man gennemfører en alvorlig samtale, gruppearbejde og rollespil med deltagelse af professionelle skuespillere, der er hyret til lejligheden til at spille rollen som patient og pårørende på scenen. De to første dele udgør den træningsplatform som de efterfølgende rollespil er baseret på. I begyndelsen af hendes mundtlige præsentation forklarer en af konsulenterne:

"Det er ikke nødvendigt, at være psykiater eller psykolog for at bruge empatisk kommunikation. Det er derimod nødvendigt, at du er opmærksom på de tegn eller de behov for empatisk adfærd, som opstår i mødet med patienten. Typisk vil disse tegn udspringe af patientens følelsesmæssige indtryk og disse vil så blive signal til din empatiske respons. I dag skal vi netop fokusere på, at træne jeres følelsesmæssige respons i bestemte situationer i klinikken".

Deltagerne får forklaret at den professionelle samtale er en patientorienteret samtale, som udgår fra patientens viden om og forståelse af egen sygdom samt 
fra vedkommendes følelser. Samtalen består af tre dele: indhold (fx at give information om testresultater); proces ( $\mathrm{fx}$ at introducere, opsummere og afslutte en samtale) og relation ( $\mathrm{fx}$ at være støttende og lyttende over for patienten). Empati, der defineres af Gyldendals encyklopædi (2012) som "indføling i en person eller andet levende væsen, ofte i følelsesbetonede situationer; evnen til at sætte sig ind i en anden persons perspektiv og følelser" introduceres her som en instrumentel færdighed, hvor en patient udover at anerkendes som et individ med følelser også må emotionelt reguleres i forhold det medicinske mødes struktur og flow.

Deltagerne forklares således vigtigheden af at "have kontrol med samtaleprocessen, så den ikke løber af med jer undervejs". Der er derfor tale om træning af udøvelse af empati og empatisk respons ud fra et sæt standardiserede (følelses-) manuskripter, hvis formål er at indramme og strukturere de emotionelle komponenter i interaktioner mellem læge og patient.

I løbet af konsulenternes præsentation skal deltagerne træne samtaler to og to. En af disse øvelser er eksempelvis en spejløvelse, hvor grupperne får besked på at kommunikere en begivenhed, som de hver for sig har oplevet $\mathrm{i}$ afdelingen til hinanden. Dernæst skal erfaringen genfortælles i alle dens detaljer, fx "hvad følte du, da hun sagde ..." eller "det var en svær situation, fordi ..." eller "jeg følte mig..." og det primære indhold i fortællingen skal opsummeres. For at udvise patientcentreret, respektfuld empatisk kommunikation og derved lære at værdsætte og sætte sig ind i den andens følelser, værdier og ræsonnementer skal deltagerne efter hver erfaringsrunde fortælle hinanden, at deres erfaringer både er meningsfulde og forståelige. Det at lytte anerkendende til andre - eller i dette tilfælde at spejle hinandens reaktioner - forklares at være afgørende for evnen til at undgå konflikt i mødet med patienten, idet anerkendende dialog fremmer samarbejdet mellem patient og sundhedsprofessionel. Hermed virker denne dialogteknik også faciliterende i forhold til de interventioner, som skal foregå i patientforløbene. Samtidig kan teknikken også være del af et "social defence system" (Menzier, 1960), der beskytter lægen i forhold til hendes personlige engagement i intime relationer.

Det næste punkt på programmet er træning i at give empatisk respons til patienter. Den mundtlige præsentation introducerer deltagerne til de generelle teknikker, som de skal bruge, når alvorlige beskeder - såsom overbringelse af en kræftdiagnose og eventuelle behandlingsmuligheder - skal gives til patienterne. Konsulenterne fortæller deltagerne, at spørgsmål (fx "hvordan har du det efter at have fået denne information"; "kan du beskrive, hvad du føler, når jeg nu giver dig denne besked"), afklaring (fx "jeg vil lige være helt sikker på, at vi er enige om det her"; "forstår du, hvorfor det næste skridt er vigtigt") og empatisk respons (fx 
"jeg kan godt forstå, hvis det gør dig frustreret"; "det lyder som om, du er meget ked af det lige nu") alle er udsagn, der giver plads til følelser. Samtidig giver brug af udsagnene lægerne mulighed for at demonstrere, at de kan udvise en form for emotionel adfærd, der kan sætte dem i øjenhøjde med patienten (jf. "partnerskabsrelationer" i Bub, 2004).

På baggrund af deres egen kliniske erfaring diskuterer deltagerne så sammen to og to, hvad der virker og hvad der ikke virker i deres møder med patienter $\mathrm{i}$ afdelingen. En af deltagerne opsummerer øvelsen ved at understrege at:

"Vi må alle være enige om, at den vigtigste ting er - uanset hvor meget vi taler om betydningen af god kommunikation og overgiver os til patientens behov - at vi må basere vores aktiviteter på vores professionalisme. Det kan der ikke være nogen tvivl om. Vi må altid handle med sikkerhed og overbevisning, og samtidig må vi være både intellektuelt og emotionelt ansvarlige. Det indebærer fx også at turde tage kontrollen med patientsamtalerne og guide disse i mål"

Der er ingen tilsyneladende modsætning i at præsentere sig selv som intellektuel (forstået som rationel) og emotionel. Deltagerne er enige om at deres professionalisme, evnen til at være anerkendende og engageret samt evnen til at styre og kontrollere den svære samtale tilsammen indrammer den svære samtalesituation i klinikken. Det betyder også, at patienterne inden for disse rammer gives en mulighed for at udtrykke relativt kontrollerede former for emotionel adfærd gennem lægernes forskellige indtryks- eller følelsesstyringsteknikker, der virker faciliterende for hvilke følelser, der kan spilles på i udvalgte situationer (jf. Goffman, 1959). Vi skal nu se, hvordan disse antagelser gør sig på en scene.

\section{Opsætning af rollespillene}

I planlægning af workshoppen har afdelingsledelsen på forhånd udpeget to typer personer som medarbejderne har erfaring med at møde i afdelingen og som de har erfaring med kan volde dem problemer i dagligdagen: en patient, som reagerer "koldt" og "inde i sig selv" samt en pårørende til en patient der reagerer upassende ved at være "alt for følelsesmæssigt involveret". De to personer repræsenterer således situationer, hvor sociale aktører mislykkes med at fremføre en forventet emotionel reaktion på en forud defineret situation. Patienten og dennes pårørende er præsenteret som personer, der enten ikke viser nogle følelser eller viser alt for stærke følelser. To professionelle skuespillere spiller rollerne som henholdsvist patient og pårørende. Deltagerne bliver bedt om at spille rollerne som 
henholdsvis læge og sygeplejerske. Før rollespillet indledes, instruerer konsulenterne performerne $\mathrm{i}$ at optræde, så deres sceneoptræden ligner en ganske normal hverdagssituation i klinikken. De skal med andre ord spille sig selv, nu tilsyneladende sat fri af hverdagens begrænsede rammer, men til gengæld observeret af et publikum, dvs. kolleger som ikke deltager i rollespillene på scenen. Performerne får at vide, at de skal huske de manuskripter de er blevet givet under formiddagens oplæg, dvs. at de skal tage indtryks- og følelsesstyringsteknikker med sig på scenen. Den fysiske scene er modelleret som et konsultationsværelse i ambulatoriet og bortset fra, at der mangler en undersøgelsesbriks, en håndvask og et skab med engangskanyler, gummihandsker og denatureret sprit, så er scenen identisk med en rigtig scene i afdelingen. Publikum sidder på stole omkring mindre borde og er klar til, at forestillingen begynder.

\section{Første akt: Patienten der er for kold}

En læge og en sygeplejerske har meldt sig frivilligt til at spille henholdsvis læge og sygeplejerske i det første rollespil. Deres opgaver er på forhånd nedskrevet på nogle stykker papir, der gør det ud for journalnotater og den første opgave er defineret som følgende:

"Kl. er 14:05 og du skal nu i samarbejde med sygeplejersken tale med patienten. Opgaven er, at informere patienten om operation samt plan for behandling, herunder indlæggelsestid - og forløb, efterbehandling (stråling/kemo) og smertebehandling".

For at udfordre performerne er der indlagt en lille forhindring i manuskriptet, som samtidig giver et personligt mærkat til patientens sygdomsfortælling, idet en note beskriver, at: "[lægen] har lige hørt fra sygeplejersken, at patienten flere gange har klaget over ventetiden". Rollespillet starter. En sygeplejerske henter patienten op på scenen og denne hilser og giver hånd til lægen. Alle tre sætter sig herefter ned omkring et bord. Patienten er en midaldrende kvinde, som er klædt i sort og bærer på en laptoptaske. Hun er irriteret over hospitalssystemet og klager over den lange ventetid i ambulatoriet, som koster hende en fridag fra arbejde. Lægen og patienten har undervejs samtaler som den, der er skitseret i dette eksempel:

"Patient: Jeg vil gerne vide, hvornår jeg skal opereres, da jeg skal finde ud af, hvem der skal tage sig af mine børn imens. 
Læge: Jeg vil finde en tid til dig med det samme. Du vil skulle møde på afdelingen ved syvtiden på selve operationsdagen [...] under operationen vil vi tage nogle prøver [...] Nu vil jeg tegne for dig, hvordan vi vil operere dig.

Patient: Jeg bor alene med mine to børn og jeg har fuld forældremyndighed. Jeg har brug for nogen svar... hvad siger jeg fx på mit arbejde?

Læge: Vi har fundet en knude i dit bryst, som jo har vist sig at være ondartet. Det betyder, at vi skal fjerne den. Vi vil lave et såkaldt sentinel node indgreb [Lægen begynder at tegne en skitse, der viser lymfesystemet i armregionen].

I løbet af rollespillet forsøger lægen at afgive de indtryk, som han i de forudgående øvelser har lært faciliterer empati. Han nikker, holder øjenkontakt og små pauser undervejs samt bruger de trænede afklarende spørgsmål "forstår du vigtigheden af din operation?" og "er vi enige om, at det er det vi gør?". Imidlertid er han ikke opmærksom på patientens tegn. Når patienten siger, at "det er svært for mig at overskue, hvad alt det her egentlig betyder ... Skal jeg være bange for, om jeg overlever kræften?", er udsagnet en oplagt mulighed for, at lægen gør brug af empatisk respons. I stedet fokuserer han entydigt på overlevering af information. Han improviserer ikke undervejs og imødekommer ikke patienten og hendes opsparede frustrationer, og han reagerer ikke på hendes forsøg på at sætte en anden agenda under deres møde - som da hun eksempelvis vil tale om sin sygdomsprognose og familiesituation. I stedet kæmper lægen med at kontrollere situationen og dens indhold. Hans udlægning af empati kan koges ned til at han registrerer patientens følelser, fx registrerer han - hvilket han også siger højt henvendt til publikum, at hun er "kold" og "afvisende" og så bruger han konsekvent et sprog, der er nogenlunde emotionelt neutralt - fx i udleveringen af information og i opremsningen af de kliniske procedurer, som patienten skal igennem. Med andre ord forsøger han at modulere patientens følelser; følelser, som velsagtens kan gøre det svært at fortsætte det standardiserede patientforløb i det han antager, at patienten ikke til fulde forstår hendes kliniske situation. Han laver denne antagelse på baggrund af, at patienten ikke afgiver indtryk af normale eller passende følelser i situationen.

En af konsulenterne afbryder rollespillet efter 25 minutter. På det tidspunkt er lægen og patienten på scenen blevet enige om en behandlingsplan og en operationsdato og de har givet hinanden hånden og sagt farvel. Konsulenten roser lægen for at have fulgt sin stramme procedureplan og for at have videre- 
bragt en klar besked om behandling til patienten. En deltager blandt publikum kommenterer:

"Han [lægen] udførte et rigtigt godt job. Der er en masse information, som vi skal nå at gennemgå $\mathrm{i}$ de meget komprimerede konsultationer, som vi har med patienten i de accelererede forløb, og han [lægen] fik dette arbejde gjort overbevisende - og uden at blive intimideret af patientens åbenlyse indstillingsproblemer. Hun er en typisk ikke-reagerende patient".

Konsulenten spørger så, hvad der sker, hvis lægen overser eller glemmer at give vigtig information og i stedet optages af andre ting under konsultationen - fx patientens manglende emotionelle respons, og hun får et direkte svar på spørgsmålet: "Så bliver vi helt sikkert nødt til at se patienten igen til endnu en konsultation" og deltageren forklarer, at:

"Denne patienttype vil formodentlig indgive formelle klager over den manglende information. De kan også nemt blive usikre og vil have svært ved at gøre sig fri af os og vil måske endog sige nej til vores behandlingstilbud. Men vi må forsøge at have opmærksomhed på patienternes individuelle behov i vores kommunikation, også så vi kan dokumentere, at vi faktisk har udført empatisk kommunikation".

Eksemplet viser hvordan deltagerne er optagede af levering af information om de procedurer, der er planlagt i de accelererede kræftbehandlingsforløb. De mere intime spørgsmål vedrørende et liv med kræftsygdom er ikke en del af deres manuskript. Manuskriptet, der dikterer de forskellige følelsesstyringsteknikker, abonnerer derfor ikke på empati i en klassisk fortolkning af begrebet, men snarere, hvad man må betegne som kontrolleret empati. I det sidste citat er det endvidere bemærkelsesværdigt, hvordan levering af empatisk kommunikation kobles på et dokumentationskrav. Det peger på hvordan emotionel adfærd i hospitalsorganisationen skal udføres på standardiserede måder hvormed det kan registreres og senere evalueres på tværs af organisationens afdelinger. Denne indsigt bakkes op i artiklens interviewmateriale, hvor en læge understreger, at tiden der bruges i afdelingen på empatisk kommunikation må registreres, så det senere kan tjene som dokumentation på afdelingens varetagelse af patientens psykosociale behov, når afdelingen har de årlige budgetforhandlinger med hospitalsledelsen. At følelsesarbejde nu gøres til et element $i$ hospitalets kvalitetsarbejde ses fx også i akkrediteringsstandarder (IKAS, 2009) og lokale kvalitetsplaner (Rigshospitalet, 2010). 


\section{Anden akt: Den pårørende som er i sine følelsers vold}

I det andet rollespil ligner både rollebesætning (læge, sygeplejerske, patient) og manuskript det vi kender fra første rollespil. Blot har patienten en pårørende med på scenen og der er indsat en ny type forhindring til lægen:

"Du er bagud med dit ambulatorium program og er først nu klar til at se patienten.

Du har ikke mødt patienten før (en kollega foretog biopsien for en uge siden og informerede her patient og datter om behandlingsmuligheder)".

Performerne får desuden at vide at den pårørende selv er uddannet sygeplejerske, og at hun er emotionelt påvirket af moderens sygdom. I løbet af rollespillet har den pårørende svært ved at forstå, hvorfor en mastektomi (fjernelse af brystet) er nødvendig for, at sikre hendes mors en god effekt af behandlingen og hun vender gentagne gange tilbage til dette emne, selvom lægen fremlægger de samme kliniske forklaringer for hende igen og igen. Den pårørende reagerer voldsomt undervejs - hun græder og råber og hun bruger sin sygeplejerskebaggrund til at kritisere, at hun selv og særligt hendes mor behandles dårligt. Lægen sidder lidt forvirret tilbage efter 20 minutters rollespil, selvom han undervejs afprøver forskellige teknikker, såsom at stille åbne spørgsmål til patienten (fx "hvordan har du det med at få denne information" og "kan du fortælle mig, hvad du tænker om dette?"). Han har allerede en gang undervejs vendt sig mod publikum og forklaret at: "det er ligesom, at et gardin er trukket ned mellem mig og patienten. Hun hører og forstår ingenting af, hvad jeg siger". Samtidig er den pårørende i den grad på banen og fremstår ifølge lægen som "i sine følelsers vold". Han signalerer tydeligt at han er i problemer. Han snubler over ordene og bruger gensvar som fx "åh", "øh" og "hm", hvilket viser at interaktionen er i en form for krise. Resultatet kan i et Goffmansk følelsesperspektiv meget vel være, at der skabes uro, dårlig stemning og at flere af performerne bliver ydmygede eller pinlige, hvis ikke situationen hurtigst muligt bliver genoprettet. Konsulenten afbryder derfor rollespillet og spørger direkte, hvad lægen foreslår som det næste skridt i forsøget på at både redde sin egen performance samt for at redde situationen som helhed, og han svarer:

"I en rigtig situation ville jeg bede patienten om at tage tøjet af og så ville jeg vise hende, hvorfor det er nødvendigt at fjerne hele brystet ved operation. Og jeg ville forklare hende, hvorfor dette valg af operation har betydning for hendes overle- 
velseschancer [...] Og så ville jeg spørge hende, om hun ikke vil lade hendes datter blive hjemme næste gang vi mødes".

Den sidste bemærkning får publikum til at grine. Som Goffman skriver, er det ikke usædvanligt at forlegenhed og spøg ofte går hånd i hånd i prekære situationer (Goffman, 1956: 271). At man laver sjov med det kan redde pinlige øjeblikke. Konsulenten spørger, hvad det komiske element i situationen er, og en deltager blandt publikum forklarer:

"Publikum:Denne kvinde [den pårørende] er bare så irriterende. Han [lægen] forsøger jo blot at udføre sit job og have kontrol med situationen. Den pårørende gør det ekstremt svært for ham at overlevere de fornødne informationer, så det videre behandlingsforløb kan planlægges"

Publikum: Først tænkte jeg, at den pårørende var ti gange værre end mine normale vanskelige patienter. Men egentlig så tror jeg, at situationen giver et udmærket billede af, hvad der sker når en pårørende forsøger at tage kontrol med situationen, fordi hun ikke kan styre sine følelser. Det er pokkers svært at vende en sådan situation om og redde den tilfredsstillende i land".

Herved bringes seriøsiteten tilbage i rollespillet ved at der peges på konfliktens alvor i den kliniske hverdag. Som en læge undervejs i workshoppen udtrykker det, er noget af det værste, der kan ske i konsultationen, at "følelserne løber af med dem [patienterne] undervejs" eller som en anden læge siger, hvis "de ikke kan styre deres følelser". En patient, der er i sine følelsers vold, udgør derfor et problem. Samtidig så vi i det første rollespil hvordan det opleves mindst ligeså stressende for lægerne, hvilket flere giver udtryk for på workshoppen, hvis patienterne ikke viser nogle følelser eller hvis vedkommendes følelser ikke umiddelbart kan identificeres som normale følelser i den givne situation. Det viser, at nogle følelsesindtryk bliver fremhævet som passende i forhold til andre - og herved er nemmere for den sundhedsprofessionelle at arbejde med. Samtidig bliver det at føle på en bestemt måde gjort til standard for normal patientadfærd, der ligger til grund for et planlagt forløb.

\section{Diskussion}

Workshoppen giver os et indblik i hvordan empati og empatisk respons kan trænes som del af en særlig optræden eller situation i klinikken, nemlig det emo- 
tionelle møde mellem patient og sundhedsprofessionel i accelererede kræftbehandlingsforløb, hvor dagsordenen er at en alvorlig sygdomsbesked skal overbringes. Derfor kan vi også retorisk spørge hvilken form for følelsesarbejde, der i virkeligheden opføres og aftales i løbet af workshoppen. Og hvad træner lægerne formelt set på workshoppen af følelsesstyringsteknikker, som de kan bringe med sig hjem?

Som tidligere beskrevet spiller begrebet empati en væsentlig rolle i skabelse og opretholdelse af emotionelle relationer mellem sundhedsprofessionel og patient (jf. Halpern, 2001; Mark, 2005). Kommunikationsteknikker, som fx anerkendende samtaleteknikker, kan bruges til at genkende patienters følelser samt give plads til, at disse følelser kan udfoldes. Dette sker dog ikke i rollespillene der undersøges i herværende artikel. Her blev det tydeligt, at såfremt en patients reaktioner genkendes som tegn på enten den ene eller den anden følelse, består den primære opgave for lægen, at styre disse følelser, således at interaktionen kan gennemføres inden for en afmålt tid. Det blev anset for afgørende at forebygge konflikter, i det konflikter kræver tid, og konsultationer i kræftafdelingens ambulatorium forventes at finde sted i en kondenseret tidsramme på cirka 15-20 minutter (eksklusive tidsforbrug spenderet på at finde et rum, koordinere med sygeplejersken, indsamle patientjournal, osv.). Forståelsen af empati som evnen til at identificere sig med en anden persons følelser, er her koblet sammen med et behov for, at kontrollere indholdet af og udbyttet af de sociale interaktioner.

Lægerne demonstrerer i rollespillene hvorledes en stor del af deres manuskript er dedikeret til at give information til patienterne. Ved at behandle kendsgerninger som emotionelt neutrale formår lægerne, at adskille følelser fra selve situationen, forblive i fuld kontrol og i stedet trække på deres faglige vokabular og formaliserede talemønstre, dvs. fokusere på mulige behandlingsprocedurer og kliniske detaljer, såsom længden på et operationssår eller farven på den kontrastvæske, der bruges i forbindelse med sentinel node teknik. De undgår herved også selv at blive emotionelt (for) engageret $\mathrm{i}$ interaktionen.

Hvis vi vender tilbage til Hochschilds (1983) begreb om følelsesarbejde, kan vi se hvorledes dette arbejde er en essentiel bestanddel af de accelererede kræftbehandlingsforløb, idet en vigtig del af lægers arbejde er, at få andre til at give indtryk af følelser på bestemte måder således, at arbejdsprocedurer kan udføres effektivt. Derfor er hovedmotivationen for at udføre denne type arbejde i behandlingsforløbene af instrumentel karakter, i det at udvise empati for patienter er en forudsætning for en accelereret udførelse af kliniske og administrative procedurer snarere end et supplement til disse. Det kræver evnen til at kunne genkende 
og kontrollere andres følelser for at kunne gennemføre forløbene på planlagt tid. På den baggrund kan vi se hvordan installationen af standardiserede kommunikative færdigheder ikke løser komplekse relationelle udfordringer i det medicinske møde $\mathrm{i}$ form af $\mathrm{fx}$ at tilbyde emotionel støtte til lidende individer. Disse færdigheder bliver i stedet et middel hvormed sundhedsprofessionelle kan distribuere neutral information og dermed kommer disses adfærd også til at afspejle en målsætning om effektiv kommunikation snarere end empatisk kommunikation.

Hos Hochschild har følelsesarbejde ydermere en dybde idet det udover at omfatte det arbejde man udøver på andre også omfatter det arbejde, man udøver på sig selv. Det sidstnævnte tillægges ikke nævneværdig værdi i løbet af workshoppen, givetvis fordi at dagsordenen er at lære at kommunikere effektivt for at facilitere de kliniske arbejdsprocesser i de accelererede kræftbehandlingsforløb frem for at lære at udøve genuin empatisk respons.

\section{Afrunding}

I studier af følelser, patientforløb og medicinske arbejdsprocesser arbejder Strauss m.fl. (1982) med et begreb, som de kalder "sentimental work". I modsætning til andre former for medicinsk arbejde understreger forfatterne at handlinger relateret til trøstearbejde, som eksempelvis psykosociale omsorgsaktiviteter til kræftpatienter ikke nødvendigvis betragtes som så eksplicitte, at de kan afrapporteres eller dokumenteres (1982: 267). Det har netop status af usynligt ad hoc arbejde og er hermed også utilgængeligt for styringsambitioner og diverse standardiseringsog kontrolmekanismer. Hochschild (1983) argumenterer på samme vis at professionelles følelsesarbejde ikke er genstand for ekstern observation (1983: 153). I modsætning til denne antagelse om at følelsesarbejde er en skjult, implicit aktivitet, hvis udførelse er overlagt til professionen selv at forvalte, viser herværende undersøgelse, hvordan empati og empatisk respons til patienter i accelererede kræftbehandlingsforløb ikke kun finder sted som implicitte, usynlige dele af medicinsk arbejde, men også som formelt organiserede performances. Herved bliver empati til genstand for styring, som noget der kan bearbejdes, standardiseres og underlægges organisatorisk regulering hvilket viser, at også bløde aspekter af medicinsk arbejde kan tjene som middel til produktivitetsforbedring. Disse aspekter kan gøres sammenlignelige på tværs af regioner, hospitaler og hospitalsafdelinger og indgå i hospitalsorganisationers eksterne strategier og udviklingsplaner.

Det aktuelle fokus i det danske sundhedsvæsen på at reorganisere behandlingsforløb, accelerere behandlingsydelser, reducere ventetider, overholde politi- 
ske garantier og styre efter økonomiske effektivitetsincitamenter udfordrer humanistiske aspekter af medicinsk arbejde. Samtidig er sundhedsprofessionelles følelsesarbejde eller lægers evne til at udvise empati i mødet med patienterne i dag et varmt emne for politikere, hospitalsdirektioner og patientforeninger. Herværende undersøgelse viser at denne optagethed af empati inkluderer en opmærksomhed rettet mod, hvem der skal levere empati; hvordan det skal ske; hvor ofte det skal ske; hvordan vi måler og evaluere det.

Fokus på lægers følelsesarbejde kan herved ses som en ny form for styring af sundhedsprofessionel ekspertise i det offentlige sundhedsvæsen. Det er en form for styring som omgives af en retorik, hvor bløde og humanistiske værdier er i centrum (jf. Harris, Clegg \& Höpfl, 2011). Dette betyder samtidig at fokus på følelser i medicinsk arbejde - som fx at vi skal have mere empati eller ligefrem empati tilbage i klinikken - ikke nødvendigvis skal ses som, at der nu også skabes plads til intime relationer i medicinske møder, men snarere er det et udtryk for, at også følelser bliver et middel til at fremme organisatorisk effektivitet. Det ansporer til en tilsyneladende paradoksal observation: når følelser og følelsesstyringsteknikker omsættes til kliniske standarder, så omdannes disse til instrumentelle midler, der har til formål at opfylde samtidens resultatorienterede målsætninger for levering af sundhedsydelser. Hermed kan også argumenteres, at sundhedsprofessionelles følelsesarbejde er påvirket af politisk moderniseringstænkning, der med afsæt i New Public Management og dennes reformelementer vægter effektivisering, prioritering, målbarhed og kvalitetsudvikling

I en forskningsmæssig kontekst er der brug for, at der bliver set nærmere på, hvordan medarbejderes følelseslandskab forandrer sig i takt med, at man indfører reformer, der skal forandre den offentlige sektor fra at være bureaukratisk og ineffektiv til at være kundecentreret og effektiv ved blandt andet at styre medarbejderes og klienters følelser.

\section{Referencer}

Bolton, S.C. (2005). Emotion management in the workplace. Basingstoke: Palgrave Macmillan. Bolton, S.C. \& Boyd, C. (2003). Trolley Dolly or Skilled Emotion Manager? Moving on from Hochschild's Managed Heart. Work Employment and Society, 17, (2), 289-308.

Bone, D. (2002). Dilemmas of emotion work in nursing under market-driven health care. The International Journal of Public Sector Management, 15, (2), 140-150.

Bub, B. (2004). The patient's lament: hidden key to effective communication: how to recognise and transform. Medical Humanities, 30(2): 63-63. 
Du Gay, P. (2000). Enterprise and its futures: A response to Fournier and Grey. Organization, 7(1): 165-183.

Fineman, S. (1993). Organizations as Emotional Arenas. In Fineman, S (Ed.), Emotion in Organizations. (pp. 9-36). London: Sage.

Fineman, S. \& Sturdy, A. (1999). The Emotions of control: A qualitative exploration of Environmental Regulation. Human Relations 52, (5), 631-663.

Goffman, E. (1956). Embarrassment and Social Organization. The American Journal of Sociology, 62(3): 264-271.

Goffman, E (1959). The presentation of self in everyday life. London: Penguin Books.

Halpern, J. (2001). From detached concern to Empathy: Humanzing medical practice. Oxford: Oxford University Press.

Harris, M., Clegg, S. \& Höpfl, H. (2011). Introduction: Managing Modernity: Beyond Bureaucracy. In Harris, M., Clegg, S. \& Höpfl, H. (Eds.), Managing Modernity: Beyond Bureaucracy. (pp. 1-11). Oxford: Oxford University Press.

Harrison, S. \& MacDonald, R. (2008). The Politics of Health Care in Britain. London: Sage.

Hochschild, A. (1983). The managed heart: Commercialization of human feeling. London: University of California Press.

Hood, C. (1991). A public management for all seasons? Public Administration, 69, 3-19.

IKAS, Institut for Kvalitet og Akkreditering i Sundhedsvæsnet (2009). Den danske kvalitetsmodel: Akkrediteringsstandarder for sygehuse.

Larson, E. B. \& Yao, X. (2005). Clinical empathy as emotional labor in the patient-physician relationship. The Journal of the American Medical Association, Vol. 293, (9): 1100-1106.

Mann, S. (2005). A health-care model of emotional labour: An evaluation of the literature and development of a model. Journal of Health Organization and Management, 19(4/5): 304-317.

Mark, A. (2005). Organizing emotions in health care. Journal of Health Organization and Management, 19(4/5): 277-89.

May, C., et al. (2006). Technogovernance: Evidence, subjectivity, and the clinical encounter in primary care medicine. Social Science and Medicine, 62(4): 1022-1030.

Mead, N. \& Bower, P. (2000). Patient-centredness: A conceptual framework and review of the empirical literature. Social Science and Medicine, 51(7): 1087-1110.

Menzies, I. (1960). A Case-Study in the Functioning of Social Systems as a Defence against Anxiety: A Report on a Study of The Nursing Service of a General Hospital. Human Relations, 13 (2): 95-121.

Miller, P. \& Rose, N. (2008). Governing the present. Cambridge: Polity Press.

Neumann, M. et al. (2009). Analyzing the 'nature' and 'specific effectiveness of clinical empathy: a theoretical overview and contribution towards a theory-based research agenda. Patient Education and Counseling, Vol. 74 (3), 339-346.

Power, M. (1997). Audit Society. Oxford: Oxford University Press.

Region Hovedstaden (2010). Kvalitet først - en kvalitetsplan.

(http://www.regionh.dk/menu/sundhedOghospitaler/Politikker+planer+og+strategier/Kv alitetspolitik+og+handlingsplan.htm). Downloadet april 2011.

Rigshospitalet (2010). Monitoreringsplan. København.

Sundhedsstyrelsen (2000). National Kræft Plan I. (http://www.sst.dk/publ/Publ2000/Kraeft/ National_kraeftplan_1.pdf). Downloadet februar 2010. 
Sundhedsstyrelsen (2008a). Sundhedsfaglige elementer som grundlag for pakkeforløb for brystkræft, (http://www.dsam.dk/files/30/b07_brystkraeft.pdf). Downloadet september 2009.

Sundhedsstyrelsen (2008b). Akut handling og klar besked: Generelle rammer for indførelse af pakkeforløb for kræftpatienter, (http://www.sst.dk/ /media/Planlaegning\%20og\%20kvalitet/Kraeftbehandling/Om\%20pakkeforloeb/akut\%20handling\%20og\%20klar\%20besked_generelle\%20rammer\%20for\%20indfoerelse \%20af\%20pakkeforloeb\%20for $\% 20$ kraeftpatienter.ashx). Downloadet september 2009.

Strauss, A., Fagerhaugh, S., Suczek, B. \& Wiener, C. (1982). Sentimental work in the technologized hospital. Sociology of Health and Illness, 4, (3), 254-278.

Teherani, A., Hauer, K. E. \& O'Sullivan, P. (2008). Can simulations measure empathy? Considerations on how to assess behavioral empathy via simulations. Patient education and counseling, Vol. 71 (2), 148-152. 


\section{Abstracts in English}

\section{On the art of life: a vitalist reading of medical humanities}

\section{Monica Greco}

In a seminal and much cited paper, Rita Charon has described narrative medicine - and, more broadly, the opening of medicine to education in the humanities - in terms of a mission to develop skills of empathy, reflection, professionalism and communication. In this paper I propose that Canguilhem's concept of vitalism and Alfred North Whitehead's concept of the 'art of life' provide a lens through which we can read the propositions of narrative medicine and medical humanities in the context of a much broader historico-scientific problematic, and connect them with a wider set of ethical and political implications. After setting out the relevant concepts by drawing on Canguilhem and Whitehead's work, in the latter part of the paper I explore the ethico-political question of how medicine might best serve the perfectibility of human beings, or the 'art of life'. I do this via a historical excursus, by revisiting a debate between Viktor Von Weizsäcker and Karl Jaspers on the merits and dangers of the 'introduction of the subject within medicine'. In their different historical context, Weizsäcker and Jaspers were able to articulate questions that remain relevant today, and that are implicit in the propositions of narrative medicine. 


\section{Credibility in illness - gender and class}

Nanna Mik-Meyer

This paper explores the intersection of gender and class concerning welfare clients with medically unexplained symptoms. The study is conducted in Denmark using qualitative interviews with welfare officers and clients. The paper's focus is on how issues of gender and class intersect in the negotiation of illness among welfare officers and clients. The particular client group in question consists of individuals that are defined by their lack of a bio-medical diagnosis. Their 'lack' of identity accentuates how gender and class become central in the categorisation practices, constructing the ill person as either bio-medically sick or as a person who may be suffering but only from diffuse psychological problems. The paper shows that it is predominantly poorly educated women without a bio-medical diagnosis that welfare officers describe as suffering from psychological problems despite the fact that the women themselves focus on physical ailments in their illness stories. Men and better-educated women are described by the welfare officers as tired and exhausted or truly stressed after a long working life.

\section{Training of controlled empathy in accelerated cancer pathways}

\section{Anne Roelsgaard Obling}

This paper takes departure from sociology of emotions to explore the training of empathy and empathic response in accelerated cancer care. The paper focuses on a training workshop in empathic communication during which doctors from a cancer clinic learn to recognise and control the emotional frame of doctor-patient interactions. Through a descriptive analysis, it addresses how communication techniques are rehearsed and it discusses the effects of this training. It is shown that the performance of communicating empathically relies on standardised scripts, which direct and cultivate the conduct of doctors. The paper concludes that contemporary reforming drives in public health care insert a renewed focus on humanistic values in medical interaction between doctors and patients, such as a focus on doctors' modes of engagement in these interactions. However, these values increasingly become the aim of techniques of micro-management such as qualitative measurement and performance audit. In other words, attempts to improve softer dimensions of medical services entail a further standardisation of these dimensions. 


\section{Everyday Trajectories of Hearing Correction}

\section{Anette Lykke Hindhede}

This paper reports on a qualitative study of the onset of acquired hearing impairment. The focus of attention is about why a person seeks treatment. The Danish welfare state serves the population 'in need' such as those with an audiological need and gives them guidance on becoming hearing aid wearers in order to rehabilitate them back to 'normal'. However, within audiological research, noncompliance has attracted much attention as investigations have shown that more than 20 percent of hearing aids are very seldom, if ever, in use and 19 percent are used only occasionally. As shown in the paper the form a problem takes is in large part a product of micro-political struggles. Hence, at the onset 'need' is often embedded in social pressure from significant others. The paper examines these two discursive frameworks and their constitution of (hearing) problems and concludes that norms of disease are complex and epistemologically contested and can help explain why noncompliance is dominant when it comes to hearing rehabilitation for hearing impaired adults.

\section{Living by numbers: The use of measurement devices in the management of life style diseases in Denmark}

\section{Bjarke Oxlund}

The advent of preventive health and medicine has led to a situation, where the risks of life style diseases are being medicated and where health understood as physical exercise and healthy diet have become a moral imperative. Many elderly Danes thus seek to manage their health condition by measuring their own bodies as well as activities of daily living through the use of devices such as weighing scales, blood pressure meters, pedometers, and bicycle computers. The results of these measurements are then matched against the scores that epidemiological surveys have established as the normal states. But what sense do people make of these measurement practices? And which bodily perception is promoted by the use of numbers? Based on preliminary insights from an ongoing fieldwork in Vordingborg municipality, this article analyzes two stories of elderly women for whom measurement of activities and bodily conditions has become a pivotal point in their everyday lives. 


\title{
Prevention across the Public and Private: When Patients Defy Empowerment and Request more Professional Involvement
}

\author{
Kaspar Villadsen \& Kathrine Hoffman Pii
}

The article presents findings from an empirical study among patients and professionals involved in a preventive health program at a Danish hospital. It shows how patients enrolled in the program interact with health professionals in ways that challenge assumptions common to governmentality studies of prevention and health promotion. This literature has successfully explored how contemporary health promotion transgresses the public/private boundary by shaping the values of collectivities and individuals to fit better with public health objectives. By exploring the complex co-existence and intertwinements of discipline and biopolitics in preventive practices this study eschews an interpretation that views the powers of the professional health system as invasive and one-directional. Instead, the study demonstrates how patients in various ways defy a 'patient-centered' and empowering approach and demand to be treated medically and disciplined in a more traditional sense. The blurring of the public/private boundary, then, cannot be straightforwardly described as a result of a professional health system that, more or less subtly, reaches into the private lives of patients. A more complex picture emerges, as patients' attitude reflect both traditional medicine and rationalities foreign to the health system.

\section{Postponing the future: on the use of causal knowledge in prevention}

\section{Morten Hulvej Rod \& Tine Curtis}

This paper discusses the heavy reliance upon a particular kind of causal knowledge in prevention and health promotion. Based on ethnographic fieldwork with prevention professionals working with interventions targeting teenage drinking in Denmark, the paper argues that, while attempting to provide predictions for the future, prevention creates certain problems for itself in the moments of social interaction where it is practiced. The paper suggests that prevention can be seen as an attempt at postponing the future and through empirical examples it is il- 
lustrated how this project causes a number of practical problems to prevention professionals. The paper begins by sketching the causal epistemology that dominates current public health research. Next, ethnographic descriptions of (i) an educational intervention in Danish schools and (ii) a meeting for parents arranged by a local public health agency provide the material for discussing the practical use of causal knowledge. It is shown that this knowledge becomes contradicted and undermined in the social interaction between public health practitioners and their target groups, and that - paradoxically - this knowledge tends to actualize the very phenomenon it seeks to prevent. The paper employs Bourdieu's distinction between two modes of anticipatory intelligence, the project and the protention, and argues that, in the interaction between prevention professionals and target group, the widespread use of causal knowledge might inhibit and counteract the situational competencies of prevention professionals. 



\section{Forfatterliste}

\section{Monica Greco}

Ph.d. og senior lecturer ved Goldsmiths, University of London. Monica er særlig interesseret i de implikationer en dualistisk tænkning i medicinen får for forståelsen af, hvad der klassificeres som hhv. sundhed og sygdom. For yderligere information om hendes forskning, se www.gold.ac.uk/sociology/staff/greco/.

\section{Nanna Mik-Meyer}

Ph.d. i sociologi og lektor ved Institut for Organisation, Copenhagen Business School. Nanna har i en årrække arbejdet med sundhedsområdet med særlig fokus på, hvordan sundhed forhandles i mødet mellem borger og velfærdsstat. Hendes publikationer tæller både videnskabelige og formidlingsmæssige tekster, se i øvrigt www.mik-meyer.com.

\section{Anne Roelsgaard Obling}

Ph.d. og ansat på Institut for Organisation, Copenhagen Business School. Hendes forskning omhandler reorganisering af velfærdsorganisationer og deres ansatte, og hun har blandt andet bidraget med artikler om styring af sundhedsprofessionelle i det danske sundhedsvæsen samt om organisering af professionelles følelsesarbejde.

\section{Anette Lykke Hindhede}

Postdoc, ph.d. og cand. mag. i pædagogik, Steno Center for Sundhedsfremme. Forskningsinteresser: forebyggelse og sundhedsfremme, diagnoser, smittes sociale liv, risikoopfattelse og sygdom i hverdagslivet. 


\section{Bjarke Oxlund}

Ph.d. i antropologi er ansat som postdoc ved Institut for Antropologi og Center for Sund Aldring ved Københavns Universitet. Hans seneste publikationer omhandler køn, forskningsetik, universitetsreformer, hiv-aids i Afrika, og aldring og teknologi.

\section{Kaspar Villadsen}

Lektor ved Institut for Ledelse, Politik og Filosofi, CBS. Han er bl.a. forfatter til bøgerne Statsfobi og civilsamfund: Foucault og hans arvingers blik på staten. (2012, med Mitchell Dean) og Det sociale arbejdes genealogi (2004). Villadsen forsker i velfærdsledelse, velfærdsstatens forandring, magtteknologier, Michel Foucault, governmentality og sundhedsfremme.

\section{Kathrine Pii}

Cand. mag. i antropologi og ph.d.-stipendiat ved Institut for Ledelse, Politik og Filosofi, CBS. Hendes ph.d. projekt undersøger, hvordan forebyggelse praktiseres i relationerne mellem sundhedsprofessionelle, patienter og teknologier og de nye former for ansvar, det forebyggende arbejde medfører for både patienter og professionelle.

\section{Morten Hulvej Rod}

Ph.d., cand.scient.anth. og adjunkt ved Statens Institut for Folkesundhed, Syddansk Universitet. Han forsker i forebyggelse med særligt fokus på unge, rusmidler og de problematikker, der knytter sig til forebyggelsens videns- og værdigrundlag.

\section{Tine Curtis,}

Ph.d., mag.art. og chefkonsulent i KL Kommunernes Landsforening, hvor hun arbejder med strategi og udvikling af de kommunale sundhedsopgaver. Tine har tidligere i mange år været forsker og forskningsleder på Statens Institut for Folkesundhed, Syddansk Universitet, hvor hun ligeledes havde fokus på sundhed og forebyggelse i kommunerne. 